\title{
Muscular Power and Endurance of the Human Body
}

\author{
As Revealed by the Mechanics of Motion
}

By Armin Elmendorf, M.Sc.

IN view $\bullet$ the increasing demand for information cøncerning the endurance of men in viølent exercise of short duration, the author recently conducted experiments to see whether such a physical quality could be represented graphically sø that it could be studied. Exercises wer selected that bring int action practically the entire bødy, such as running up a steep incline, swimming, running on a level track, and by weight lifting. The first of these exercises would be represented in military functions, for example, by a charge and the last would be tiøns, for example, by a charge and the last would be quite analoge te was made to determine the amøunt of work men can do in long perieds of time such as in the eight-høu day, nør was it the purpese to estimate human pøwer in terms of the unit, the horse-pøwer, when effort was controlled and extended •ver several høurs of time. The investigation was limited to a study of endurance when working continueusly at the very peak of exertion as in a race or in variøus military perations.

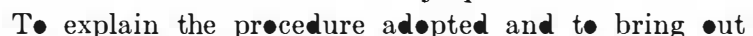

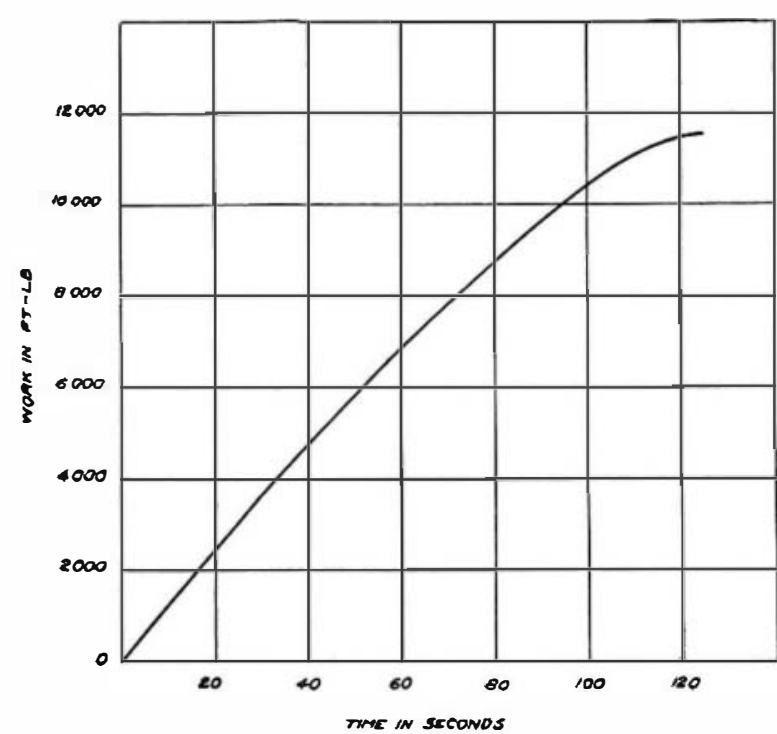

Fig. 4. Work-time curve for person raising a 32.5

lb. weight from the floor to the height of reach

the significance $\bullet$ the results it is necessary first t• •utline in søme detail the exact meaning of the terms work, pøwer, energy, and speed, and to differentiate between them. First in regard the use of work it must be thor ughly understood that the peration it expresses independent and absolutely unconcerned with time. A host of ants marshalled int harness would by working many weeks do exactly the same amøunt of work in carrying a half dozen sacks of wheat, grain by grain, up to the farmer's attic as the farmer himself carrying a sack at a time. The science of mechanics defines work as the product of force inte distance. This definition does n॰t bring in the nøtion of time. Inasmuch as work is the product of two factors its unit of measure must

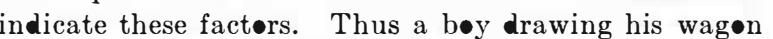
up hill may exert a pull of 20 pøunds. When he has pulled the wagen through a distance of 10 feet he has done 200 foot-pounds of work. A man weighing 150

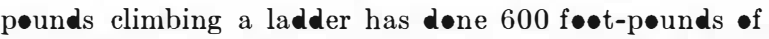
work when he has ascended 4 feet, irrespective of whether

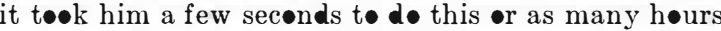

While the use of the term work demands some explanWhion, this is till more imperative in regard to power and ation, this is till need in showing the variety of uses to which the latter

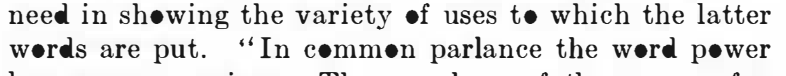
has many meanings. Thus we hear of the pøwer of a

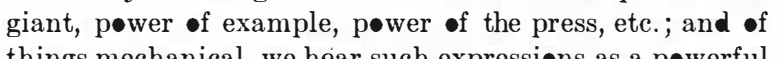
things mechanical, we hear such expressions as a pøwerful

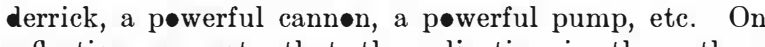
reflection we note that the adjective in these three

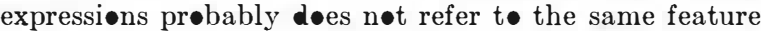
-f the derrick, cann $\bullet$ and pump. A derrick is prøbably called pøerful because it can lift a very heavy bødy, exert a great lifting force. A cann pøwerful because it can prøject a heavy shøt with great veløcity. A pump is prøbably called pøwerful because it can elevate $\bullet$ r transport a large quantity of liquid in a short space of time, or perform much work per uni time." The word is here used to express three distinct ideas, in the case of the derrick it means force, in the *Instructor in Mechanics, University of Wisconsin, Madison.

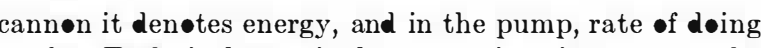
work. Technical termin $\bullet$ logy restricts its use to the last idea entirely. Power is defined as the rate of doing work. T• the tw factors necessary to define work we must add the third, time. By extreme exertion an invalid weighing 150 pøunds may climb 4 feet in 10

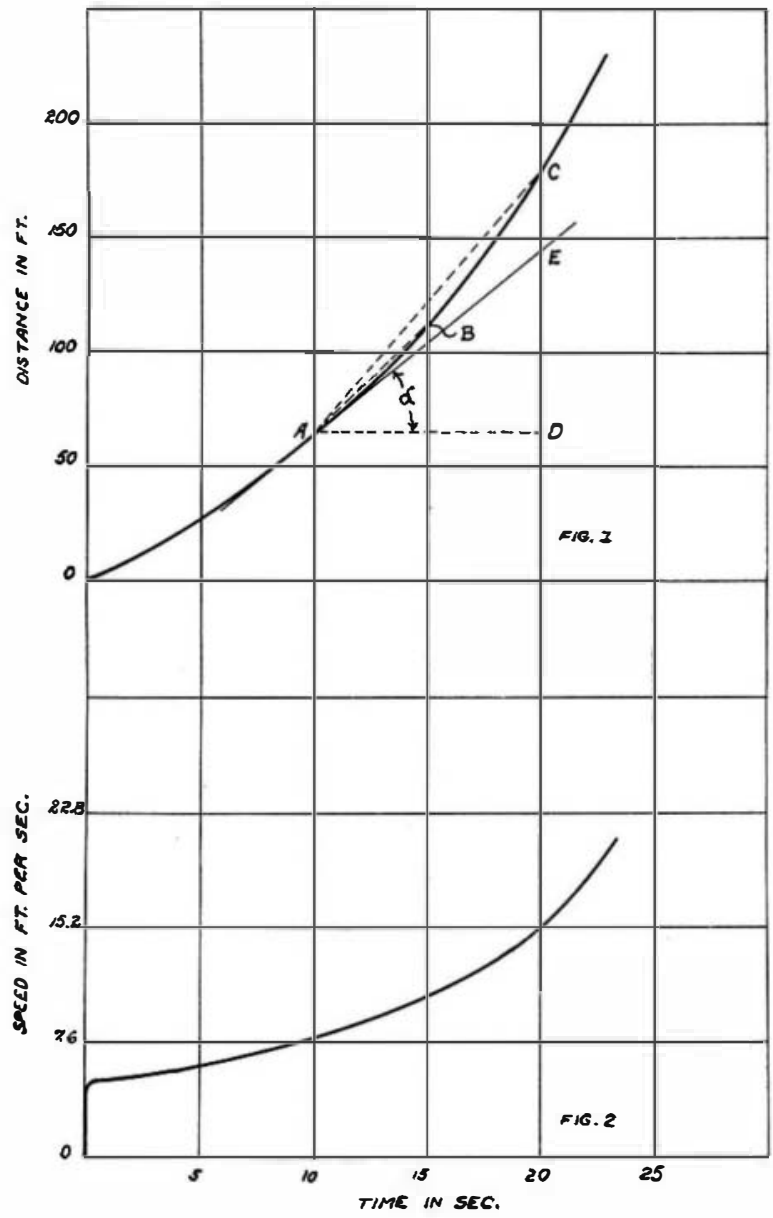

Figs. 1 and 2. Distance-time and speed-time curves for a person assumed to be running on a horizontal track

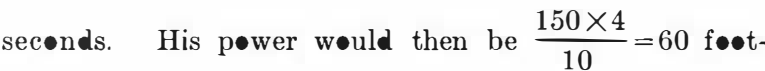
pøunds per secønd. A normal man of the same weight by maximum effort may be able to de the 4 feet in 3

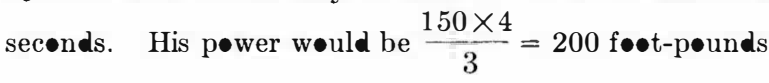

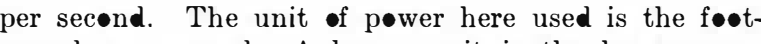
pound per second. A larger unit is the horse-pøwe

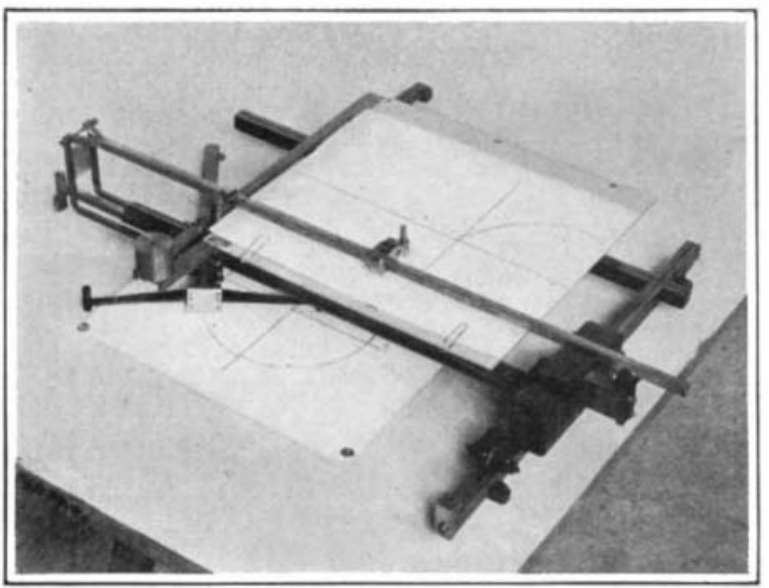

Fig. 3. The author's differentiating machine

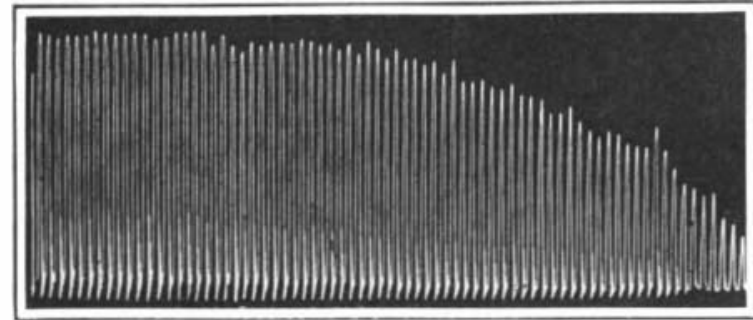

Fig. 6. Fatigue curve traced by an ergograph, showing effect of exercise in increasing the force of the muscles

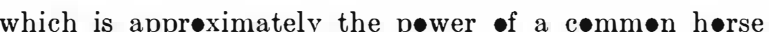
working a day and is defined as the pøwer of the machine which does 550 føot-pøunds of work in $\bullet$ ne second. The normal man climbing the ladder has $200-:-550=0.364$ hørse-pøwer for the short peried of 3 seconds.

As an interesting diversion to determine the horsepower a normal person exerts in ascending stairs at a rapid pace, the author conducted a few trials with persons of varying weight running upstairs from the first to the fourth floor of an office building. The time re to the fourth floor of an ofice building. The tine require was on the average about 14 seconds and the pøwer for this time interval ranged frøm .7 tø 1.2 hørsepøwer for the different individuals.

The definition of pøwer intrøduced the idea of rate,

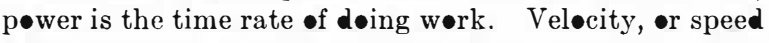

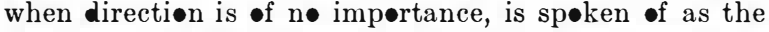
time rate of displacement. It will be necessary t• distinguish average speed from instantane us speed.

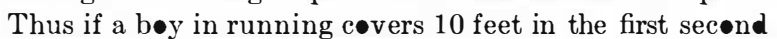

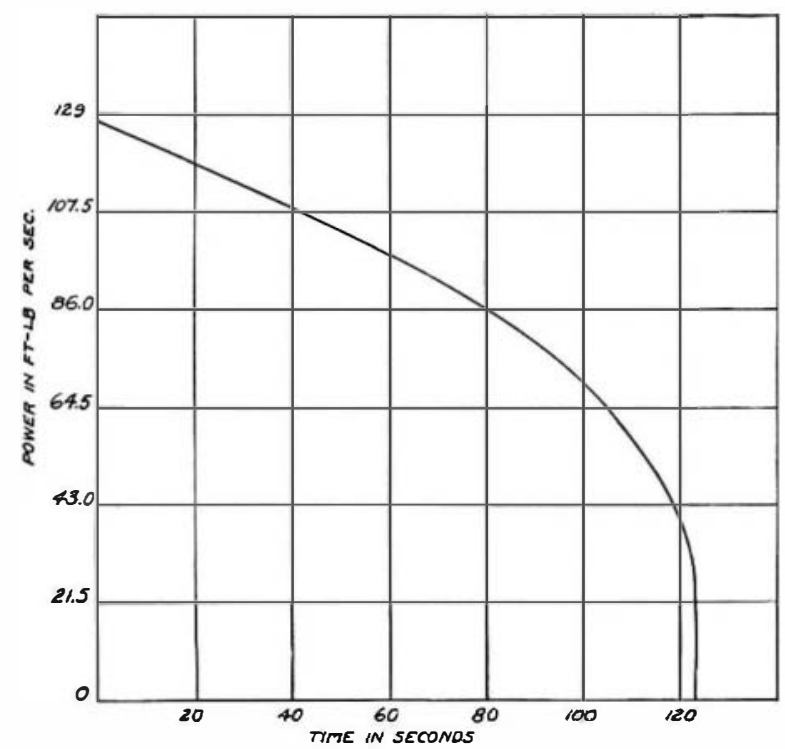

Fig. 5. Power-time or endurance curve obtained from the work-time curve of Fig. 4 by differentiation

his average speed is 10 feet per second for the first second. If he covers 12 feet in the next second his average speed for the second interval is 12 feet per second and his average speed for the first tw॰ seconds is $\frac{10+12}{2}=11$ feet per secønd. If he covers 14 feet in the third second his average speed during the third second is 14 feet per secønd and his average speed for the first three seconds is $\frac{10+12+14}{3}=12$ feet per secønd, etc. The bøy's speed is changing continuously as he runs, and the

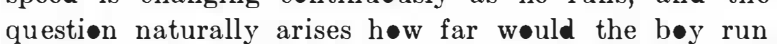
question naturally arises høw far would the bøy run his speed remained constant; in other words what is his instantane us speed at the end of three seconds?

Let us attempt t• find a runner's instantane@us speed at the end of the tenth second. We will need søme data f $\bullet$ this purpøse which may be readily •btained. By placing persøns with støp watches at unif $\bullet$ rm intervals aløng a running track, say at 20 -f $\bullet \bullet t$ stations and starting all watches at the instant the gun is fired and the run is begun, the time to reach each station will be bbtained. This may be plotted against the distance. Such a graph is shown in Fig. 1. From this curve it will be seen that is shøwn in Fig. 1. Frøm this curve it will be seen that
at the end of 10 seconds the distance cøered is 65 feet and at the end of 20 seconds the distance is 180 feet, s• that the average speed for this ten second interval is $(180-65) \div 10=11.5$ feet per second. It is represented gemetrically in the triangle $\mathrm{ACD}$ by the rati $\bullet \mathrm{CD}$ to AD. In $\bullet$ ther words the average speed is given by the tangent of the angle CAD. Similarly the average speed for the interval from 10 to 15 seconds is given by the tangent of the angle $\mathrm{BAD}$ and is here $110-65=9$ feet per second. N॰w as the time interval is taken shorter and shorter the point $\mathrm{B}$ approaches $\mathrm{A}$ and the chord $\mathrm{AB}$ approaches as a limiting position the tangent to the curve at $\mathrm{A}$ while the angle $\mathrm{BAD}$ approaches the angle the tangent at A makes with the horizental, that is the angle $\propto$. But the average speed is measured by the angle the chord makes with the horizontal, and since the chord approaches the tangent as a limit as the 
time increment becomes indefinitely small, the angle between the tangent and the horizontal measures the limiting speed, that is the speed at the instant when ten seconds have elapsed. This means that if the runner has kept up exactly the same speed for the next ten seconds as he had at the end of the tenth second the distance he would cover during that interval would be given by $\mathrm{DE}$.

T• preceed frøm the given distance-time curve t• the instantaneous speed-time curve sh॰wn in Fig. 2 is a simple matter. At the ten second division on the hørizontal line we will erect to søme scale the value of the tangent of the angle at $\propto \mathrm{A}$, at the 15 second division the value of the tangent at the angle $\propto$ at $B$, etc. Connectene ing these pointe gives the smooth speed-time corve of involved is quite large. The author's differentiatin machine of Fig. 3 performs the entire $\bullet$ peration mechanically, thereby saving a great deal of time. It has for it function the plotting of the tangents withøut measuring the angle, performing the $\bullet$ peration $\bullet$ the calculus kn॰wn as differentiation. ${ }^{1}$

One step further takes us from the speed-time curve to the pøwer curve, f०r by simply multiplying veløcity by force we get pøwer. Thus if a man raises his weight against the force of gravity at a certain speed as in climbing a ladder or in running up stairs, he exerts

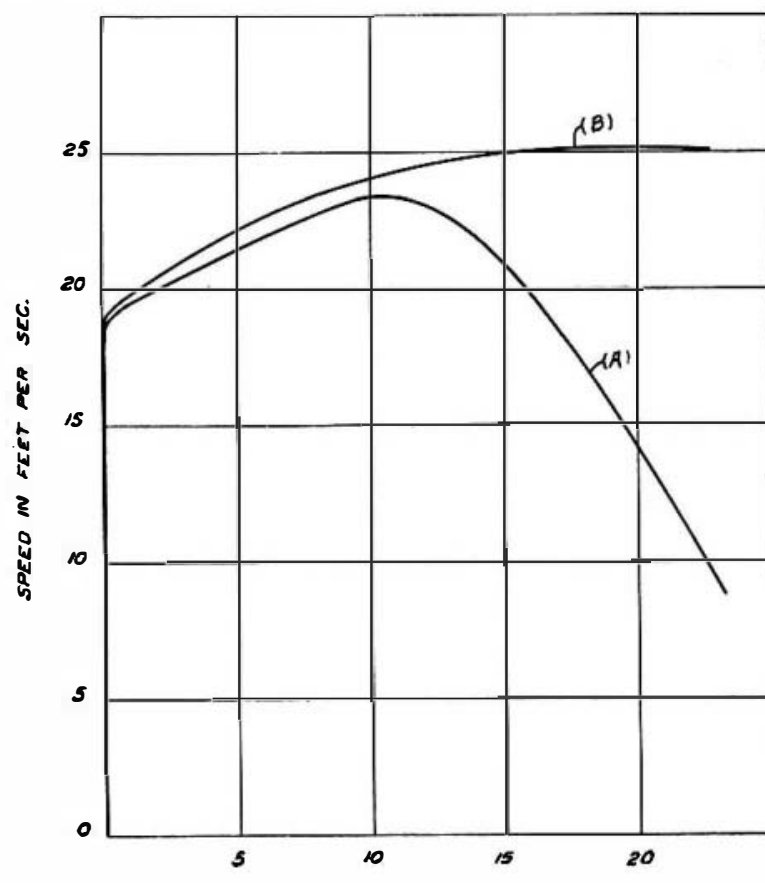

Fig. 7. Distance-time curves in SEC men running up-hill

a distance of $450 \mathrm{ft}$. $A$ is the curve of an untrained man but a good runner, and $B$ is the curve of an athlete

pøwer; and the pøwer a man has rather than the instantaneous force he can exert measures his effectivenes in action, that is his endurance.

To determine the endurance of the human bødy for work demanding primarily the use of the back, shøulder and arm muscles an experienced weight lifter was aske and arm muscles an experienced weight lifter was asked
to raise a 32.5 pound weight from the fløor to his height - f reach. The distance through which the weight wa raised multiplied by 32.5 gave the work done in each lift The time for each five lifts was read, giving all the data the work-time curve of Fig. 4. Operating upen this curve with the differentiating machine gave the curve of Fig. 5 which may be called the endurance or power curve for this particular individual in weight raising. Different weights would of course give curves varying both in weights would of course give curves varying both in
height and length. The points to be noted in Fig. height and length. The points t• be n॰ted in Fig. are first that the maximum pøwer is $\bullet$ btained at the start,
as may be expected, and that the pøwer decreases uni formly with time up t॰ the end of tw॰ minutes, when the expenditure of energy had reached the point at which

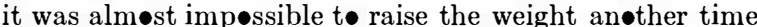
and being completely exhausted the man "gave up" It must be berne in mind that the weight lifting was It mith a maxime the the the The initial pøwer of 127 feet-pounds per sec $\bullet$ or 0.23

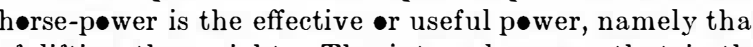
- lifting the weight. The internal pøwer, that is the p॰wer expended in lowering the weight and in raising an

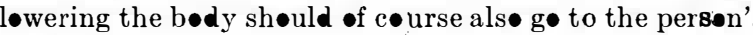
credit but it is sø indeterminate that it was n c considere here. Prøbably if these expenditures were kn॰wn the maximum power developed would have been very near one-half horse-pewer.

The remarkable similarity between the pøwer curve

${ }^{1}$ A description of the differentiating machine will be found in the Scientific American Supplement of February 12, 1916,
and The American Mathematical Monthly, October, 1916. and the rdinary fatigue tracing should be noted. Fig. 6 shøws a tracing $\bullet b t a i n e d$ by Prøfessør Aducco ${ }^{2}$ t॰ bring -ut the effect of training on the strength of muscles. The tracing was made by ergøgraph, an instrument recording the range through which a weight is lifted by a finger. The curve is in reality als• a pøwer curve Since the abscissae represent time and the ordinates are equally spaced, each ordinate stands for the work done during the same time interval, that is power. Like the fatigue tracing, successive pøwer curves will indicate

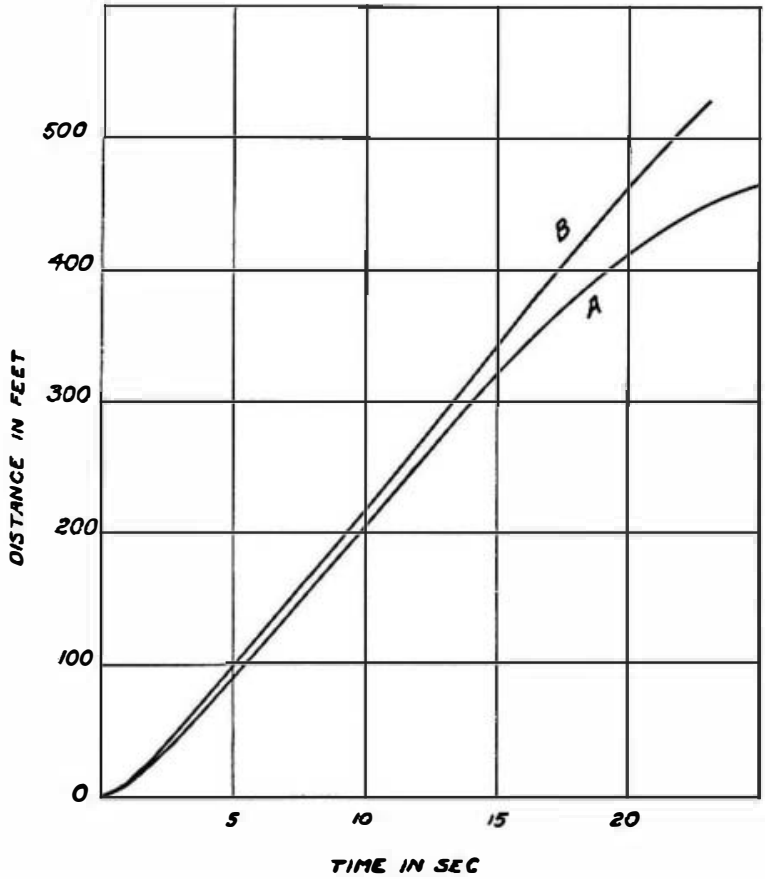

Fig. 8. Speed-time curves obtained from the distancetime curves of Fig. 7 by differentiation

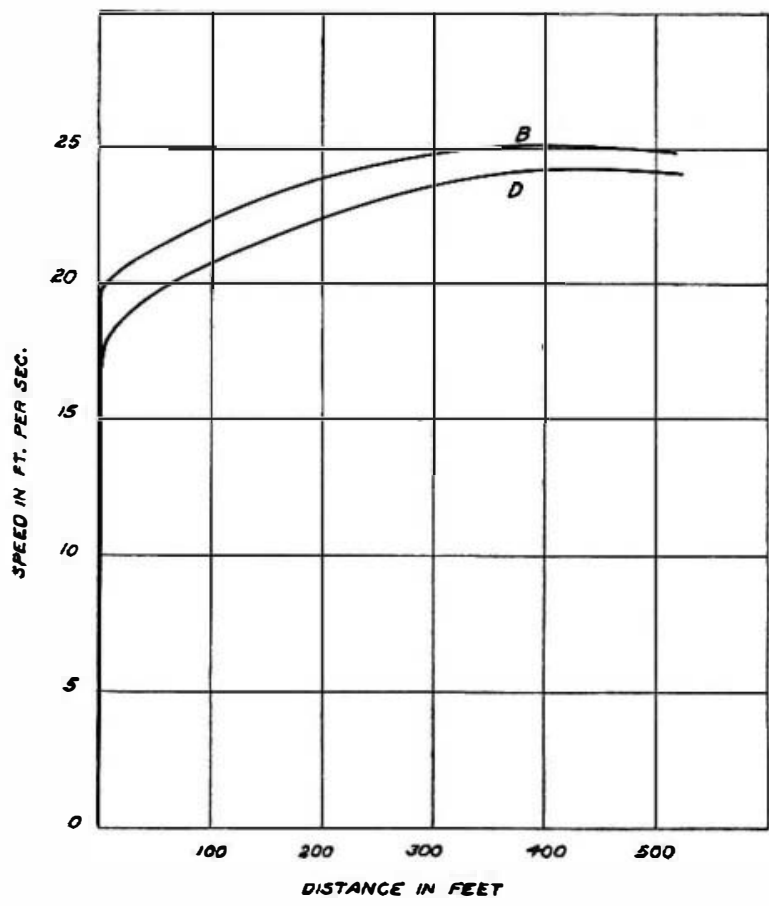

Fig. 9. Speed-distance or endurance curves for trained men running up-hill

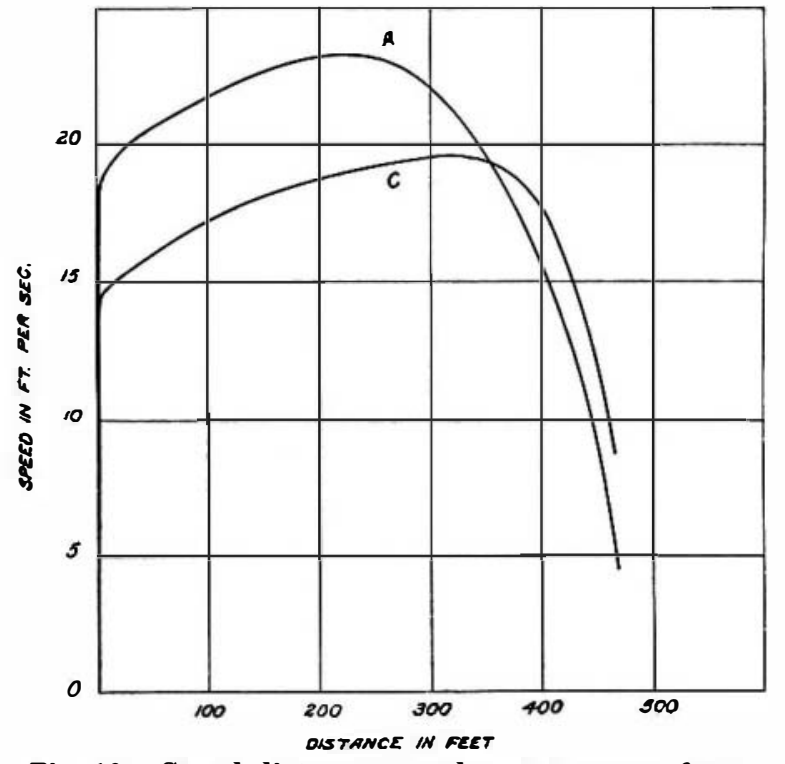

Fig. 10. Speed-distance or endurance curves for untrained men running up-hill

2Fatigue by A. Mosso, translation by Margaret Drummond and W. B. Drummond, page 95 imprøvement in endurance. A study of pøwer curves taken at various times while a person is under training should present a fertile field of investigation, one that would be of great interest and importance to athletic directors and officers in charge of military training camps.

As a second measure of endurance, tests were made on men running up hill. Fifty føot intervals were marked -ff $\bullet$ a walk having a unif $\bullet$ rm grade of 10 per cent, and rec॰rders with støp watches were stationed at each division. At a given signal all the watches were started and the runner left his mark, the time being taken at the instant the runner passed each of the stations. This data plotted gave curves of which the tw॰ in Fig. 7 are representative. $A$ is the curve of an untrained man and $B$ that of an athlete. Inasmuch as the walk upon which the test was conducted had an uphill grade of 10 per cent, each 100 feet passed •ver represents the work of lifting one's weight vertically through a distance of 10 feet. Now if the runner reaches a maximum speed - 25 feet per second he raises his weight 2.5 feet per

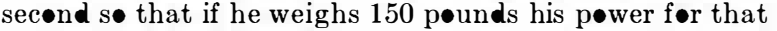
speed is $\frac{150}{5} \times 2.5=0.68$ h०rse-p•wer. Multiplying veløcity in the vertical direction by weight gives the pøwer in f॰ot-pøunds per second and dividing by 550 gives it in

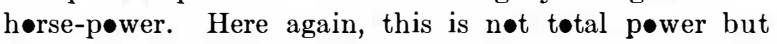

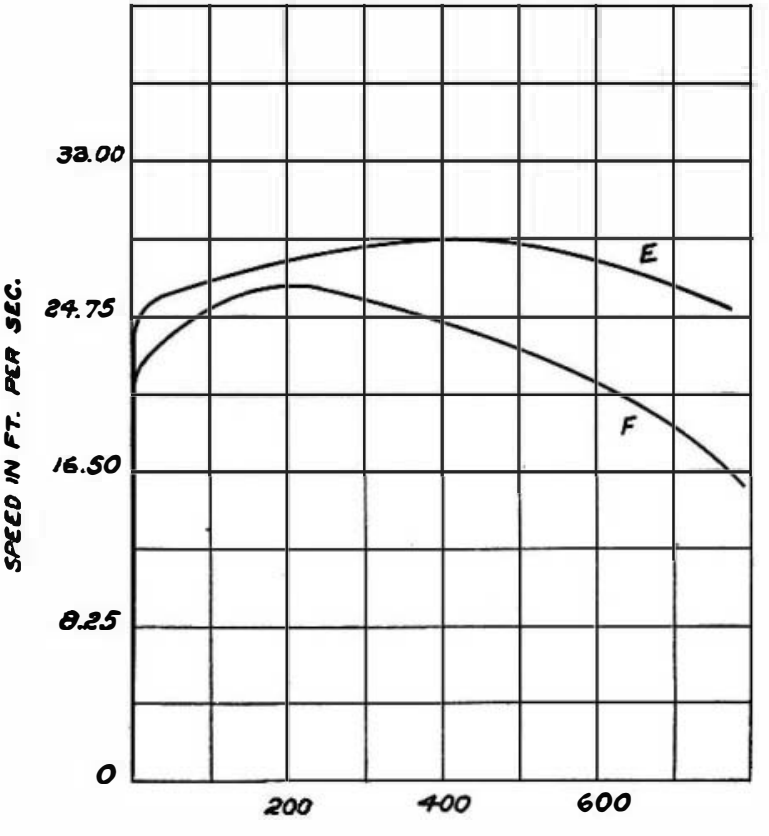

DISTANCE IN FT.

Fig. 11. Speed-distance or endurance curves for two men running on a horizontal track distance of 800 feet

-nly what may be called external pøwer, namely that $\bullet$ working against the external force of gravity. T॰ •btain

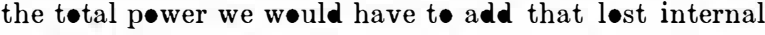
work such as bødy friction, radiation, etc. By analogy it

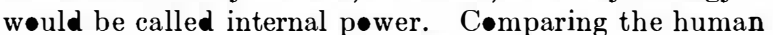
body as a machine with the steam engine we might say

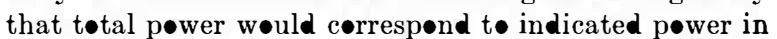

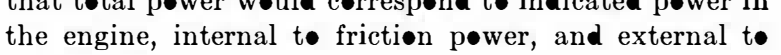
brake power.

The curves of Fig. 8 are the result $\bullet$ operating upøn the distance-time curves of Fig. 7 with the differentiating machine. While the ordinates represent speed, they

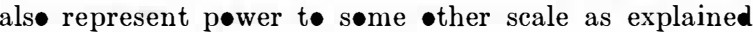
Figure \& then is a graphical record of endurance in running uphill. Two points are signifeant, fint that runger uphill Two points are the case in weight lifting but in the interval from ten the twenty seconds after the start, secønd, that the peak to twenty seconds after the start, second, that the peak
once attained the pøwer of the untrained man falls very once attained the power of the untrained man falls very rapidly while the trained man løses pøwer $\bullet$ nly gradually. In a charge the soldier must possess enough energy after having reached his destination to execute his orders -f attacking or "digging in." His capacity of doing this is measured by the ordinate to the power curve at the time corresponding to his supposed arrival at the destination. The psychølogical element enters $\bullet$ c curse, but it is not unreasønable to assume that courage is as much determined by pøwer as pøwer is the result of courage.

Figures 9 and 10 sh॰w the variation of pøwer with distance. The curves were btained by finding the speed at certain instants from the speed-time curve and the distance at the corresponding instants from the distance-time curve. B and D of Fig. 9 are the curves of trained runners, $A$ and $C$ of Fig. 10 the curves of untrained men. The effect $\bullet$ training is s- •bvious that explanation is unnecessary. We can readily imagine the difference in execution of which $\mathrm{B}$ and $\mathrm{D}$ are capable 
after having run 450 feet in comparisøn with $\mathrm{A}$ and $\mathrm{C}$. The ideal time for action would corres-

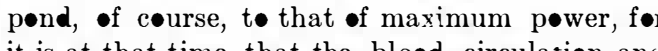
it is at that time that the blood circulation an musclo stimulus have reached the intensity for the best eff $\bullet$ rt $\bullet$ which the individual is capable. In Fig. 11 are given the speed-distance curve of tw• men running $\bullet$ a hørizental circular track -ver a distance of $\mathbf{8 0 0}$ feet. Here again the maximum speed of the trained runner $\mathrm{E}$ is both greater and occurs at a later time than that $F$, an untrained man, and the falling off powe which is necessarily measured by speed alone is more rapid in the latter curve. In such axe more rapid the bødy remains on the same level, hence no sumed in internal work, that is power in running sumed in internal work, that is pøwer in
in a horizontal track is entirely internal. in a horizontal track is entirely internal. The endurance curves of Fig. 12 are for thre -ne characteristic in commen, namely that the maximum speed or power is attained at the very start as is the case in weight lifting. The curve $A$ is for a 100 yard dash man, B for a 200 yard swim, and $\mathrm{C}$ the curve of an untrained swimmer trying his time on a 60-yard swim. The preceding curves,

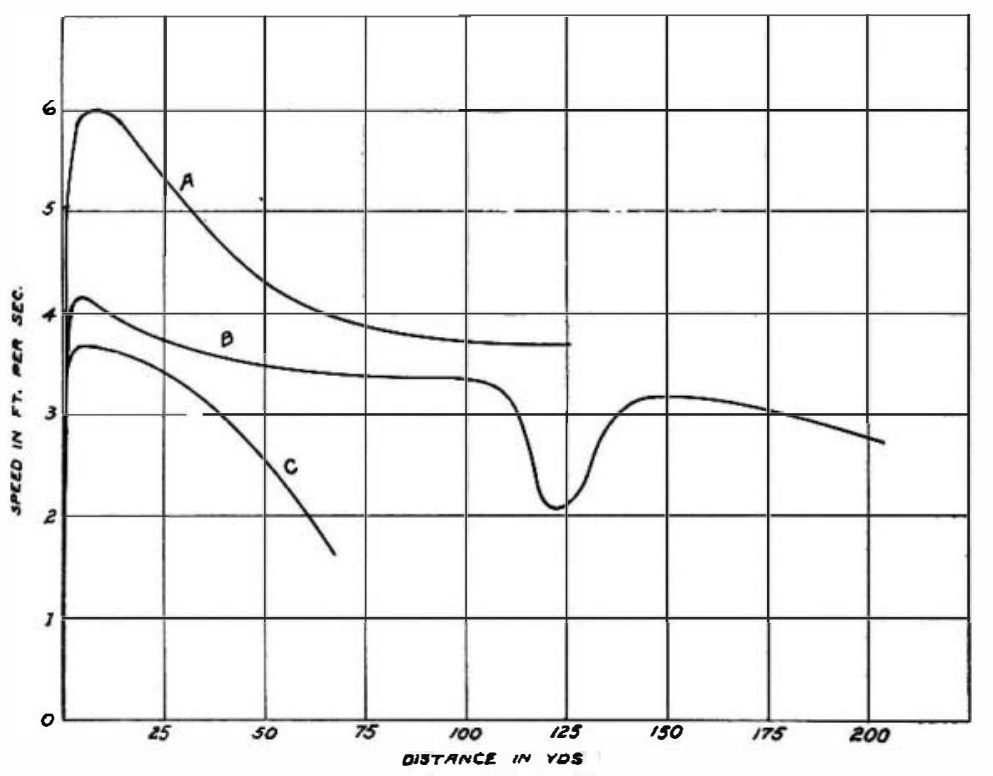

Fig. 12. Endurance curves for men swimming

namely the distance-time and speed-time curves were -mitted because they showed nothing further than is shown in the speed distance curves of the figure. The marked dip in B's curve at 135 yards indicates a slowing up for a short distance, possibly to catch the "second wind." A swam a crawl strøke and $B$ and $C$ each swam the breast strøke.

While the speed distance curves give a gøod graphical representation of endurance or pøwer the total muscular pøwer expended cann $\bullet$ be accurately determined, not even in running up stairs althøugh here most of the energy gøes int raising the body against the force of gravity and thus may be measured. It seems reasonable to assume that since the maximum speed in running up hill is 25 feet per second and the speed for running on a horizontal track is only 4 feet per second more, and the power expended by a normal person in raising his weight when doing 25 feet per second up hill $\bullet$ a 10 per cent grade

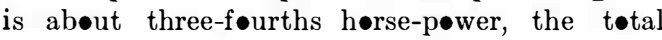
pøwer in running up hill must be cønsiderably more. A retardation of 4 feet per second enables the man to raise his weight vertically 2.5 feet per secend, that is, the retardation correspends

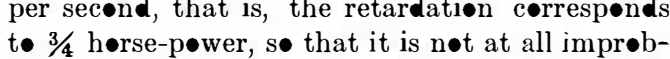
able that a gøod runner doing a 220 yard dash exerts able that a gøod runner doing a 220 yard dash exerts
himself during the run to the extent $1 \frac{1}{2}$ hor se-pøwer.

\section{Explorations in the Hawaiian Islands}

Durı Ng last summer, Prøf. A. S. Hitchcøck, custødian -f the section of grasses of the division of plants, U. National Museum, assisted by his søn, A. E. Hitchceck, traveled in the Hawaiian Islands studying and collecting the flora, especially the grasses, making what might be termed a forage survey.

The islands visited were Kauai, Oahu, Lanai, Møløkai, Maui, and Hawaii, these comprising all the islands of the

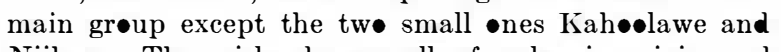
Niihau. These islands are all of volcanic origin and composed of lava, except a very small part which is of coral formation. Kauai, geologically the oldest island, shøws the greatest effect of erøsion, its deep canyons shows the greatest effect of erøsion, its deep canyons
rivaling the beauty of the Grand Canyon of Colorado. rivaling the beauty of the Grand Cany $\bullet$ of Cølorado.
The rainfall on the mountains of the windward side is excessive, that $\bullet$ Waialeale, the highest peak $\bullet$ Kauai, being as much as 600 inches per annum. On the contrary, the lee side of the islands is arid, the rainfall being -ften reduced to less than fifteen inches per annum.

T• the south the islands are successively younger Hawaii, the largest, being even n॰w in a state of volcanic activity. On this island are situated the two highest peaks of the grøup, Mauna Kea, 13,825 feet, and Mauna L•a, 13,675 feet in height. There is scarcely any vegetation upon these peaks, above 10,000 feet, especially

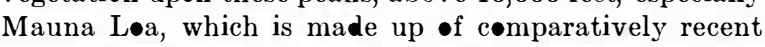
lava. Much sn॰w covers the peaks in winter, extensive banks persisting throughout the year. The magnitude -f the mountain mass is greater than at first appears, because the cones arise from the very floor of the ocean, 18,000 feet below the surface, thus making the total

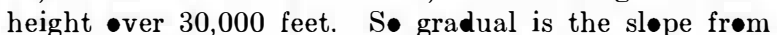
the sea to the summit, that the eye is deceived and the great height is not at first fully appreciated. The active

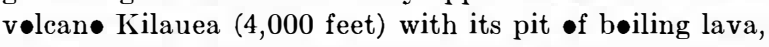
is •n Hawaii, while Healeakala, said to be the largest crater in the world, is $\bullet$ Maui, the second largest island of the group.

Important agricultural industries of the island include sugar, live stock, and pineapples. The native Hawaiian population is decreasing, and it is only in the less accessible parts of the islands that the primitive custøms still prevail. Here may be found the native grass huts made of a wooden frame-work filled in with a thatch of grass. The grass used for this purpose is usually pili, an indigeneus grass abundant up॰n the rocky søil -f the løwlands.

The cultivated trees and shrubs are of great variety and beauty, and are drawn from all tropical and subtrøpical land. The introduced flora is very pronøunced in the region of the towns, ranches, and plantations, and

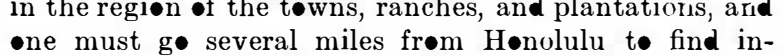

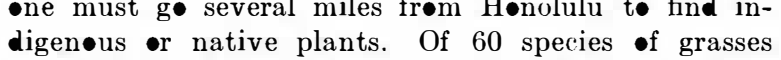
digen $\bullet$ or native plants. Of 60 species of grasses
f und $\bullet$ Oahu abøut fifty were intrøduced frøm føreign

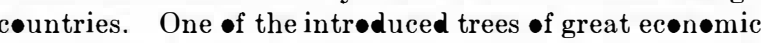
importance is the algarøba tree, or kiawe, as the Hawaiians call it. It is found in a belt on the lowlands along the shores of all the islands and •ccupies the søil almost to the exclusion of other plants. The pods are very nutritious and are eagerly eaten by all kinds of very nutritious and are cagerly eaten by all kinds of høney. The Møløkai ranch aløne prøduces 150 to 200 tons of strained honey per year. The prickly pear tons of strained honey per year. The prickly pear has become extensively naturalized in the dryer portions -f all the islands. Ranchmen utilize this for feed when -ther kinds become scarce, the cattle eating the succulent jøints in spite of the th॰rns. Tw• introduced

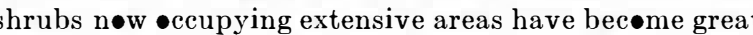
pests. These are guava, whose fruit furnishes the delicious guava jelly, and lantana, with clusters of

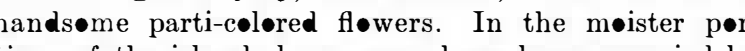
tions of the islands large areas have been $\bullet$ ccupied by Hilø grass which has little value as a forage plant. The kukui or candlenut tree with its light, almost silvery,

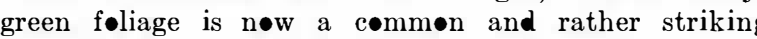
element in the valleys and gorges.

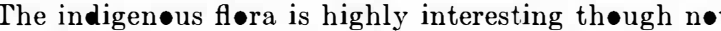
abundant in species. Tw $\bullet$ of the commonest trees are

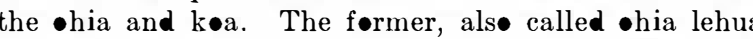
and lehua, resembles, in the appearance of the trunk, - ur white •ak, but bears beautiful clusters of scarle fløwers with long protruding stamens. The køa prøduce a valuable wood much used in cabinet making, n॰

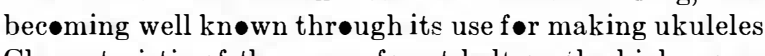
Characteristic of the upper forest belt on the high mountains of Hawaii is the mamani, a leguminous tree with

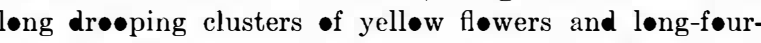
winged pods constricted between the seeds. In the arid regions is found the wiliwili, a deciduous tree with gnarly grøwth. Its bare branches are conspicuøus, a deciduous trees are unusual in the trøpics. It ha very soft light wøod, and bright scarlet seeds. Amøng the peculiar plants of the islands is the silversword, strikingly beautiful compøsite with glistening silver leaves, which grøws $\bullet$ nly $\bullet$ the sløpes $\bullet$ cinder cønes in the crater of Haleakala and in a few very limited localities •n Hawaii. The family Løbeliaceae is represented by about 100 species belonging to six genera. The numerøus arbørescent or tree-like species are ver peculiar and characteristic. Many of them form slender trunks like small palms, crøwned with a large cluster of løng narrøw leaves. The trunks of søme species are a much as 30 •r 40 feet high and the large bright-colored flowers are sometimes remarkably beautiful.

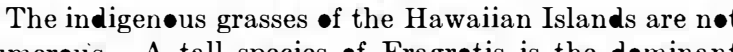
numerous. A tall species of Eragrotis is the dominant

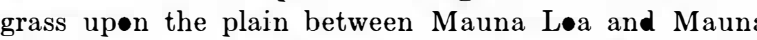
Kea. Upøn many of the summits of the high mountain ridges in the regions of heavy rainfall are føund •pen ridges in the regions of heavy rainfall are found ope Many species form møre or less hemispherical tussøck

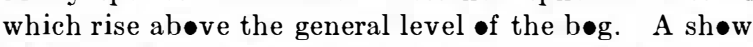
løbelia with numerøus large cream-colored fløwers as much as three and one-half inches long, peculiar vi॰lets, and a sundew are found there. These bøggy areas are dev $\bullet$ id of trees and sømetimes $\bullet c c u p y$ rather extensiv areas, the $\bullet$ ne $\bullet \mathrm{Mt}$. Waialeale cøvering several square

Three species of tree ferns are found on the Island and in søme places form extensive forests. These plant produce at the base of the stipe, a great ball $\bullet$ br bowish-
yellow wo॰l called pulu by the natives and used by them f॰r stuffing pilløws and mattresses.

\section{Potato Flake Process}

Even with the best care, it is impossible to avoid the decomposition and germination of potatees, and th

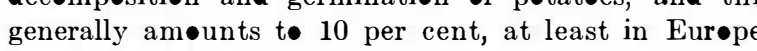

Within the last twenty years the method of preserving

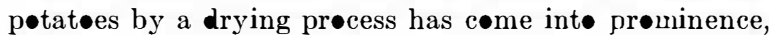
and especially in Germany where their consumption is considerable. It is stated that the number of plants for this purpose has n॰w greatly increased. Dried

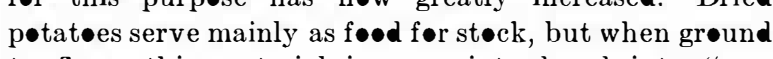
to flour, this material is even introduced int• "war bread." Potatoes contain 70 to 85 per cent $\bullet$ water and this must be reduced to 17 or 18 per cent in the dried product. Starch forms the main part of this dried

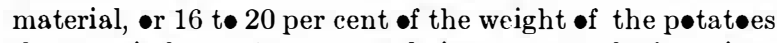
the remainder or 5 per cent being composed of various substances. In spite of many efforts, n• success has

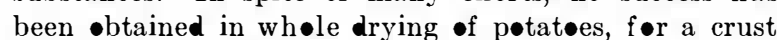
is formed during the $\bullet$ peration which prevents the prøper drying of the inside, and again this does not give a good industrial prøduct. Theref $\bullet$ re the pøtatøes are cut up in pieces or in thin slices and put through the drying machine. A more recent methød is to reduce the potatøes to a pulp by a treatment with a jet of steam, then this

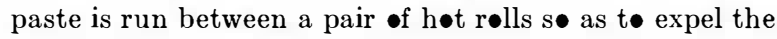
water. The resulting product appears in the shape of very light flakes. The following is a summary description of a plant for treating about one ton of pøtat॰es per hour: After passing the washer and cleaner on the ground floor, the pøtatøes are brought by a conveyor to the tøp story and stored in a høpper, and frøm here they pass by way of an automatic weigher int the machine proper which first reduces them t• paste and then runs this between the cylinders. The upper part of the

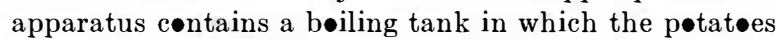
are treated with exhaust steam from the engine, then they drop int the reducing chamber where sets of paddle wheels or rather cylinders crush up the mass and form the pulp or paste. Without leaving the machine, the paste runs vertically between tw• large heated cylinders, and the dried and flaky substance coming through is scraped off the cylinders by suitable means. It falls to the bøtt $\bullet \mathrm{m}$ of the machine containing a breaker, frøm whence a pneumatic conveyor takes the small flakes t•

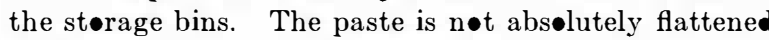
between the cylinders, for these are mounted søme 0.06 inch apart, and before gøing through, a thin layer of paste has been already formed on the cylinders by suitable scrapers placed at the top and a well-combined feeding device. Great regularity is required in the feed and in the spacing of the cylinders, før if the layer is n॰t of unif $\bullet r m$ thickness, the thin points bec $\bullet$ me ver-dried and take a brøwnish cølor. This, høwever, can be avoided by proper precautions. Steam te the amøunt of $80 \mathrm{lbs}$. per $100 \mathrm{lbs}$ of potates is usually employed for

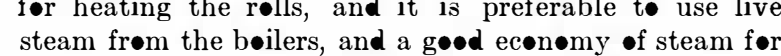
the whole process has been secured in this apparatus. The flakes cøming frøm the present prøcess form a very light material which is n๑t easy to put up in sacks, sø that it requires to be put under press, using generally the type of press employed for treating hops and the like, or again, a screw press such as is used in sugarmaking for pressing beet slices. In this way the flakes are reduced to a smaller mass and are usually put up in are reduce to a smaller mass and are usually put up in now entered int real industrial practice in Germany, will be seen from the fact that the product from the whole number of plants for the year 1916 amounted to n* less than 4,000,000 tøns. 